\title{
GRAZING USE OF FOREST LANDS ${ }^{1}$ BY W. R. HANSON 2
}

\section{INTRODUCTION}

I am going to talk about grazing use of wild forest lands on which there are multiple resources leading to coincidental uses. It is somewhat paradoxical that specialized papers on single uses should be presented on this programme because the basic concept of multiple-use of wild lands demands that the managers be generalists rather than specialists in the individual uses-timber, grazing, wildlife, recreation, watersheds. They must comprehend the interplay of the special fields when they need technical aid, but good multiple-use management must keep all uses integrated with the others, in harmony with the natural capacities of the resources and in economic balance among themselves.

\section{SCOPE AND LimitaTIONS}

It is my intention to discuss my subject, not as a specialist, but as a generalist. Use of forest land by range livestock will be considered in its relation to other simultaneous uses of the same land. Conflicts between grazing and other uses will be discussed, and it is my intention to show that in the final analysis grazing is a legitimate and proper use of forested wild lands and that it fits nicely into the multiple-use concept, even to a point of being a helpful tool in the management of such lands.

I would like to point out here that when $I$ attempt to show how livestock use of wild lands is acceptable, I refer to grazing use under proper range management. I would be the first to admit that improperly managed, or unmanaged, grazing use may inhibit timber production, conflict with big game, destroy camping areas and damage watersheds.

\section{SAMple AREA}

To illustrate some of my points I am going to refer to the Crowsnest Forest, one of the three forests administered under the Eastern Rockies Forest Conservation Board. I have not chosen this Forest necessarily because it is representative or gives average conditions but because its multiple-uses are rather highly developed. It is the most southerly of the three forests lying on the east slope of the Rockies and comprises the drainage basin of the Oldman river with a small part of the Waterton thrown in.

The country is typical of the Eastern Rockies, changing quickly from rolling foothills to precipitous crags. The cover consists of grassy southern exposures, valley Hats and meadows, poplar and willow growth on the lower slopes, pine and spruce at higher altitudes where protection and soil are favourable with scrub growth, bare rock, and alpine meadows at the extremes of altitude. Although most of the area bears a cover of trees, considerably less than half the area produces timber. The grassland, the popular stands, the open pine

\footnotetext{
1 Paper presented at the annual meeting of the Canadian Institute of Forestry, Banff, Alberta, October 11-13, 1951.

: Eastern Rackies Forest Conservation Board, Calgary, Alberta.
} 
and the occasional Douglas fir stands, produce forage for domestic livestock and big game.

There are three main branches of the river and numerous creeks. These rank among the best fishing streams in Alberta. The valleys have scenery comparing with that of Banff and Waterton Parks. There are several large herds of elk, numerous deer, some sheep, goats and moose, as well as furbearing animals. About 73,000 cow months of grazing are harvested each year by domestic livestock. About 20,000,000 F.B.M. of lumber and about 12,000 lineal feet of mine props are harvested annually. Four strip coal mines operate inside the Crowsnest Forest and considerable drilling for oil has been done.

It is very evident that this is a multiple-use area in which several industries are actively engaged: lumbering, ranching, dude ranching, mining, trappingand in which fishing, hunting, camping and other recreations are important.

\section{Importance of Grazing Use to Economy of the Surrounding Area}

It is an accepted fact that agriculture is the backbone of the economy of southwestern Alberta and that ranching is the branch of agriculture most important to the foothills. The use of the forest reserve is mainly for summer grazing of cattle kept on the home ranches and farms during the winter. Some 14,000 cow units ${ }^{3}$ (as cattle, sheep and horses) are run annually on the Crowsnest Forest and they harvest about 73,000 cow months of grazing. This brings an income of about $\$ 36,500$ to the reserve. The actual beef produced by the cattle while on the reserve is very conservatively estimated as being worth $\$ 365,000$ at last year's prices. Over 200 farmers and ranchers run cattle on the Crowsnest Forest which makes an average gross income of about $\$ 1,800$ per operator from beef on the forest range. The total amount of beef is not as important to the industry as the part it plays in balancing up land use in the foothills. The rancher can send part of his cattle into the mountains for summer so he can put up hay on his meadows to carry the stock over winter. The farmer sends his cattle away while he grows his grain crops and then winters the stock on the aftermath and the cover crop which he plants on his summer fallow. His operation is thus balanced up by the use of Forest Reserve for summer grazing and his land thereby becomes more valuable.

The return from grazing fees is second only to stumpage and is an important revenue to the government. The use of the forest for summer grazing is important to the livestock industry especially in making for a better balance in the use of the farm and ranch lands.

\section{EFFECT OF GRAZING ON OTHER Uses}

For many years forested land, especially in western North America, has been grazed by livestock. Parts of the Crowsnest Forest, to which I have referred several times, were grazed before the area became a Forest Reserve, and this use has continued since. The manager of multiple-use land should know

3 A cow unit or animal unit is defined as a 1000-pound cow with calf at foot. A cow month one month. 
the relations existing between grazing and other simultaneous uses so that he can evaluate the proper place for grazing in multiple-use. On the east slope we consider grazing by domestic livestock and big game as a legitimate use which can be integrated with timber production, recreation and water yield. Let us consider the relationship of grazing by domestic livestock and big game upon timber production, recreation and watershed value.

Timber: it has often been stated that livestock use is destructive to seedlings and damaging to reproduction. Much study has been made on the subject so let us examine the literature. In the south, Gemmer (2), working with Lobolly pine (Pinus taeda) and Wahlenberg (14) working with longleaf pine (Pinus palustris), found that cattle grazing caused some damage to reproduction-but that it could not be regarded as a serious factor. Stickel and Hawley (11) found that the benefits of proper grazing with sheep and cattle in New England pine plantations far outweighed the damage done, while Ninman and Thompson (7) concluded that over-pasturing eastern white pine (Pinus strobus) woodlots is highly detrimental. In the southwestern United States, Krauch (5) investigating Douglas fir (Pseudotsuga taxifolia) concluded moderate grazing by cattle is beneficial to reproduction, while Hill (3) concluded that the effect on ponderosa pine (Pinus ponderosa) reproduction is largely neutral. In the same region Pearson (9) finally concluded that properly managed grazing is beneficial to the establishment of ponderosa pine and is, in fact, an important management tool in controlling plant succession and reducing fire danger. Ingram (4) found that damage to Douglas fir reproduction on the Pacific Coast caused by moderate grazing was of minor importance. Young et. al., (15) working with western white pine in Idaho concluded that moderate grazing by sheep is beneficial to white pine reproduction and has little effect on other timber species, while over-grazing is detrimental to reproduction of coniferous species, white pine least of all. They concluded further that grazing may assist in re-seeding an area of white pine.

Grazing, even when heavy, did not cause serious erosion on the porous, granitic soil of the Clearwater region. Grazing cut-over forest at a comparatively early stage plays a major role in the rate of successional development which is apparently an important consideration in the silvicultural management of the Clearwater cut-over lands since height and composition of the forage species can be partially controlled. Tisdale (13) working in the interior of British Columbia in ponderosa pine, Douglas fir and spruce-fir types concluded that grazing fits readily into a multiple-use program in forested areas of the interior of British Columbia. Moderate Grazing, he concluded, does not appear inimical to watershed maintenance.

The literature on the subject of grazing of timber land by domestic livestock brings out two important facts that are useful in managing multiple-use land. First, over-grazing or improperly managed grazing is usually damaging to timber production. It is pertinent that all cases quoted in which damage occurred, grazing was intensive and otherwise badly managed. The second important point is that properly managed grazing caused little or no damage and 
is considered to be an important silvicultural tool in controlling succession and to some degree useful in lowering fire danger.

Grazing by big game is often neglected in its effect upon the forest, especially by those who claim that anything "natural" is "good" and anything man-controlled is "bad". Research on the subject shows that carefully managed populations of big game may occupy forest lands without great damage, but if allowed to over-populate the area serious damage occurs, especially on their winter range. To illustrate I would like to refer to some work done by Lowell Adams of the United States Fish and Wildlife Service on whitetail (I) deer range in Norhtwestern Montana. On the Fisher river in Lincoln County the timber stand is dominated by ponderosa pine. There is evidence that pine is being replaced by Douglas fir, an economically inferior species. A high population of 7,000 whitetail deer show a distinct preference for pine seedlings over fir and are eliminating the pine. The author points out that over-population has. suppressed the browse species normally forming the deer diet and that they have turned to conifer by necessity. The result is poor timber reproduction and of a less desirable species and poor watershed condition.

\section{Livestock Grazing and Big Game}

Although the place of wildlife in multiple land use is outside my topic, the relationships existing between big game and domestic livestock and between both and watershed values are so close that some consideration of game seems pertinent.

There is some competition between livestock and big game for forage and habitat, but this has been found to be less than generally expected. Stoddart and Rasmussen working in Utah (12) state that it is entirely possible to produce both deer and livestock on the same range. Deer not only graze different forage plants from those eaten by domestic livestock, but they also. inhabit somewhat different areas.

Competition between elk and livestock is greater than that between livestock and any other game animal because of greater similarity in food habits and natural habitat. Elk, in Alberta, normally ranged from the foothills far into the plains over the ranch country of today now used almost exclusively by domestic livestock.

The late Orange Olsen in a paper given at the Northwest Scientific Association now published in "Elk Below" (8) states that winter range is in general the limiting factor, and if these winter grazing lands are properly used from a game management standpoint the possibilities of conflict between big game and livestock will be greatly lessened. He further points out that competition between species exists only when use results in over-grazing of the plants palatable to both species.

The problem of managing big game on wild lands is closely tied up with sociology. The demand for recreation in the form of hunting has increased tremendously in the last decade. In the hunting season hundreds of cars rush to the hills, and where a few fish and game clubs used to struggle for 
existence, every town has its association with memberships into the thousands in the larger cities. These associations usually set conservation of game and fish as their main objective. Often they become pressure groups attempting to influence legislatures and government agencies regarding the laws and regulations concerning game. This is all to the good except when the regulations for which they press are falsely based. Too often their requests are based upon "barber-shop biology" instead of sound principles. An example of this is the general opinion that there should be an unlimited population of big game in our forest reserves to supply shooting for all who want it. The principle that the population of any species is limited by its environment, especially the available food supply is lost sight of. The pressure for continuation of the buck law and opposition to harvesting the increase of a herd to keep it in balance with the food supply are results of this loose thinking. It should not take a trained biologist to know that a population cannot be kept at a static level by shooting part of the males only, yet opposition to taking cow elk and does reaches a fever pitch when mentioned at a fish and game association meeting. I am reminded that the Hindus are not unique in their belief in the Holy Cow - our barber-shop biologists seem to have equal worship for the cow elk.

Eventually the wishes of the recreational hunters brings about demand for the removal of domestic livestock from the publicly owned forest reserves. Then conflict with the ranchers flares up and each group starts calling the other names. Sociologically the problem may be difficult but physically the solution on the range lies in the application of a few sound principles which I am going to repeat here:

1. Competition between species (game or domestic livestock) exists only when use results in over-grazing of the plants palatable to both species.

2. The population of any species is limited by the environmental factors of food, water, protection from enemies, and shelter.

3. The factor of the environment which is limited or lacking will be the limiting factor in population increase.

4. In multiple-use management the various uses must be integrated and where one use is more important than the others those uses must be subordinated to the one which is economically more important.

To apply these points to the management of elk on the east slopes of the Rockies makes the problems appear quite solvable. Water has come to be considered the prime resource and therefore use by elk and domestic livestock must be subordinated to watershed values. Elk generally move into the higher and rougher country in summer and do not use the same area as cattle. Before settlement of the foothills they moved far out, even onto the plains in winter. Now that their winter range is under settlement, they are forced to remain on the few grassy, open hills, or sheltered browse types inside the forest reserve or trespass on the ranchers. The winter range is, therefore, the limiting factor and poor watershed conditions as a result of over-use have already been noted on much of the elk winter range.

The first step in managing the elk herds is to limit their numbers to 
the capacity of the winter range. Then livestock use should be limited and controlled so as to leave the winter range best suited for elk unused. This is relatively easy to do. Cattle, in their summer use of the Reserve, do not prefer browse nor the coarser bunchgrasses that grow on the higher slopes and ridges, but these are the species which make good winter grazing for elk. The plants which cattle prefer are the softer grasses and forbs of the bottomlands and poplar groves where snow becomes too deep in winter for use by any animals.

Therefore, if an area is grazed lightly enough by livestock that the watershed is kept in good condition the forage most important for elk winter use will be left. Then, if the population of elk is kept in balance with the winter range no damage to the watershed values should result. This, of course, requires careful watch on the size of the elk herds and laws and regulations which allow for a take equal to the increase of the optimum herd. Naturally both males and females must be taken.

It may seem wasteful to a rancher to see 60 per cent of the forage left on the ground, to eventually decay, but actually it is the opposite of waste good conservation. The 60 per cent of the bunchgrass forms surface litter which slowly rots and is carried downward into the soil as humus. The litter on top and the organic matter in the soil make the difference between an impervious soil which erodes with the run-off and a friable, porous soil which soaks up water for plant use or to be carried to the water table and streams. The former soil grows poor forage crops and is an unsatisfactory watershed while the latter produces abundantly and ensures the optimum in watershed conditions.

\section{GRAZING AND RECREATION}

Little needs to be said regarding the conflict of grazing and recreation. Well managed cattle or sheep ranges can continue to be valuable recreation areas. However, certain scenic spots and camp grounds must be reserved and livestock use eliminated theref rom. Cattle have a habit of shading up in the cool shady nooks suitable for camping and picnicking and who wants to sit down on, or next to, a cow pie when settling down for lunch?

\section{GRAzing ANd Watershed Values}

The relationships between watershed value and any other use are the most important concern of the wild-land manager. There was a time when we considered air and water as limitless and free but that time has gone. This is pointed up by the plight of New York City and other urban centers in trying to meet the demand for water. We are rapidly reaching the point where all our water supply will be needed. I know of a community in the intermountain region of the United States where they were forced to choose between using their water supply for a war industry which the government wished to establish and for irrigation. There just wasn't enough for both.

Mont Saunderson (10) in his book "Western Land and Water Use" points out the value of water yielded by the National Forests in the Western 
United States. He places an annual value of $\$ 258,000,000$ on water, more than the value of timber, grazing and recreation combined for the same area. To come nearer home the annual value of water from the Crowsnest Forest, as carried by the Oldman River, (using Saunderson's value of $\$ 1.75$ per acre foot) is $\$ 1,806,000$. Much of this water is unused but all has potential use. This is more than the annual production of beef and timber combined, and possibly recreation added.

As has been pointed out the broad problem of watershed management is to get the water which falls in the form of precipitation (at least as much of it as we can) down to the streams in an orderly fashion and out to where it is used at the most useful season. Recent investigation has lead watershed managers to conclude that their objective can best be attained by upstream protection and management. Manipulation of the ground cover is one of the most important, if not the most important procedure of upstream management. Not only has it been demonstrated that livestock use under good range management is not damaging to watersheds, but it may be a tool in the manipulation of cover. True multiple-use management is being applied when grazing is not merely allowable along with water yield, but is integrated to serve a purpose in improving water production.

It is not necessary to refer to literature to point out alarming examples of devastation of watersheds by bad livestock use. These have been written up in the popular literature and depicted on the motion picture screens over the country. Fortunately what is good management to supply the maximum sustained yield of grazing results in favourable watershed conditions, and this is almost without exception. In our part of the country conservative use is necessary to sustained forage yield and good watershed conditions. Experimental results tell us that we cannot use more than 40 per cent of the forage in our bunchgrass types and still keep them in a productive state.

Both game and livestock grazing without proper management may have a damaging effect upon watersheds. The classic example of damage noted in game management literature is the case of the Kaibab plateau on the north rim of the Colorado Grand Canyon. There the elimination of predators with no control of deer population allowed numbers to exceed the forage resource to the point of devastation of vegetal cover. Deer were actually seen standing on hind legs browsing from ponderosa pine. Wtih the destruction of vegetal cover the soil mantle lost its ability to soak up precipitation and carry it to underground storage and streams. Gullies formed everywhere and rapid run-off carried tons of sediment. Needless to say no pine seedlings established themselves. Eventually deer died like flies in winter for lack of food. It is interesting to note that examples of big game damage to watersheds are always examples of mismanagement of game.

Some recent investigations by the United States Forest Service on the 
Eastern Rockies in Colorado (1) points out the importance of organic matter to good watershed conditions:

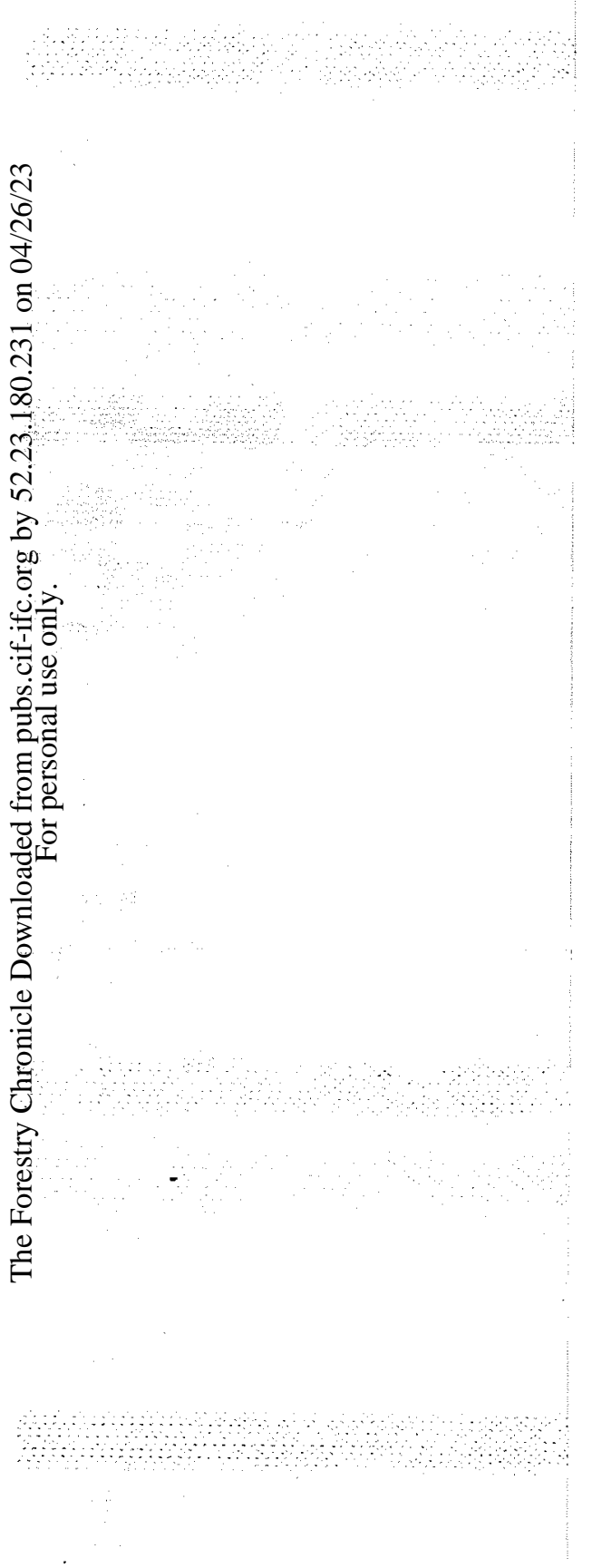

\begin{tabular}{|c|c|c|c|c|c|c|}
\hline & Runoff & $\begin{array}{l}\text { Infiltra- } \\
\text { tion } \\
(2)_{1}\end{array}$ & $\begin{array}{l}\text { Soil } \\
\text { Lass } \\
\\
(3)\end{array}$ & $\begin{array}{l}\text { Live } \\
\text { Vegeta- } \\
\text { tion } \\
(4)\end{array}$ & Litter & Total \\
\hline Bood: & 4 & 4.7 & 99 & 1895 & 10238 & 12133 \\
\hline $\begin{array}{l}\text { Poor: } \\
\text { Bunchgrass }\end{array}$ & 23 & 3.6 & 646 & 1304 & 9306 & 10610 \\
\hline $\begin{array}{l}\text { Poor: } \\
\text { Aspen } \\
\text { Depleted: }\end{array}$ & 22 & 3.6 & 315 & 734 & 11827 & 12561 \\
\hline Aspen & 25 & 3.9 & 171 & 137 & 12715 & 12561 \\
\hline
\end{tabular}

(1) Per cent of precipitation.

(2) Inches per hour during last 20 minutes of a 50 minute test.

(3) Pounds per acre during 50 minute test.

(4) Pounds per acre, air dry.

This work indicates that over 6 tons per acre of raw or partly decomposed organic matter and live vegetation is necessary to keep bunchgrass type watershed land in proper condition. This coupled with results which show that productivity of range can only be maintained when 60 per cent of the annual yield of bunchgrass returns to the soil shows that conditions of good grazing and good watershed are similar if not identical.

Summarizing results of investigations into the relationship of grazing and other uses of wild land, we are safe to say that properly managed grazing fits nicely into multiple-use land management in western Canada where watershed value holds a place of prime importance. Over-use by livestock and improperly managed use should not be tolerated on any of our wildlands, and if tolerated are certain to result in eventual economic loss.

The question then arises as to what constitutes good range management. This is hard to generalize upon since good management practices vary with every grazing unit. There are, however, certain principles that must always be applied.

Carrying Capacity. Use must always be in balance with the grazing resource. To the manager this means making a resource inventory, deciding upon allowable use and then applying livestock feed requirements. On the East Slopes we are using a method which involves the estimation of plant density, estimation of the plant composition by species and applying a proper use factor to each important species. A simple arithmetic computation gives a numerical "forage acre factor". This multiplied by surface acres gives the forage resources in "forage acres". This forage acre is the unit which we use in all our calculations. It comes much nearer to being a constant in evaluating grazing than a surface acre. 
When the range manager comes up with an estimate of carrying capacity, he is still not finished as it must be tested under actual practice. Carrying capacity is not a fixed quantity like the capacity of a bucket. John Jones may run 500 head of cattle in an allotment using good management and keep the range in excellent condition, whereas Joe Doakes may run only 400 in the same area and do much damage. Capacity depends upon management efficiency.

The test that must be applied is the condition which results from the range use. This requires constant checking on the part of management using a set of standards of conditions.

Proper Season of Use. It is an accepted fact that early season use puts greater pressure on grazing than later use. There is a stage of plant development before which the range should not be used. To find this stage requires considerable study of the relationship of plants to weather or seasonal development - phenology we call it. With seasons as they are this stage of development does not fall upon the same calendar date every year. The date of range readiness should, therefore, be set every year. Plant indicators of range readiness can be found. Some which we use in southwestern Alberta are glacier lily (Erytbronium sp.) to indicate "too early" and balsamroot (Balsamorrbiza sagittata) to indicate range readiness.

Livestock Handling. The most important thing in handling the livestock is to keep use as evenly distributed over the area to make full utilization without damage to certain parts. This is the most difficult managerial problem and the efficiency of a livestock operator on forest range can be judged by the distribution of the livestock use.

Range Condition. Regardless of the details of livestock management upon multiple-use land, the criterion is the resulting condition of the land. For proper management this requires setting up of standards of condition which must be met. These standards in general are based upon:

a. Composition of the vegetation (the climax plant community is usually sought.)

b. The carry-over vegetation for the litter cover in relation to bare ground.

c. Soil - the stability of the soil, infiltration capacity and lack of erosion.

d. Reproduction of the desired species - in the case of timber land the timber species should be given first consideration.

\section{BIBLIOGRAPHY}

1. ADAMS, Lowell. The Effects of deer on Conifer Reproduction in Northwestern Montana. Jour. Forestry 47 (11); 909-193, 1949.

2. GEMMER, E. W. Loblolly Pine Establishment as affected by Grazing, Overstorey and Seedbed Preparation. Jour. Forestry $39(5) ; 473-477,1941$.

3. HILL, Robert R. Effects of Grazing upon Western Yellow Pine Reproduction in the National Forests of Arizona \& New Mexico. U.S.D.A. Bulletin 580, 1917.

4. INGRAM, Douglas C. Grazing as a Fire Prevention measure for Douglas Fir Cut-over Land. Jour. Forestry $26(8) ; 998-1005$. 
Б. KRAUCH, H Some Fretors Infuencing Douglas Fir Reproduction in the Southwest. Jonr. Forestry $34(6) ; 601-608,1936$.

6. MeGINNIES, W. G. 1950 Annual Report Rocky Mountain Forest and Range Experiment Station.

7. NINMAN, H. J. \& THOMPSON, W. C. Effects of Pasturage on White Pine Repraduction and on Timber Quality. Jour. Forestry 25(5); $549-554,1927$.

8. OLSEN, Orange A. Elk Below. Published by Friends and Agsociates, Manufactured by Stevens \& Wallis Inc.

9. PEARSON, G. A. Grass, Pine Seedlings and Grazing. Jour. Forestry, $32(5) ; 545-555$ 1934 .

10. SAUNDERSON, M. H. Western Land and Water Use. University of Oklahoma Press, Norman, Oklahoma.

11. STICKEL, P. W. \& HAWLEY, R. C. The Grazing of Cattle and Horses on Pine Plantations. Jour. of Forestry $22(8) ; 864-860,1924$.

12. STODDART, L. A. \& RASMUSSEN, D. I. Deer Management and Range Livestock Production. Utah State Agri. Experiment Station Circular 121.

13. TISDALE, E. W. Grazing of Forest Lands in Interior British Columbia. Jour. Forestry 48 (12);856-860, 1950 .

14. WAHLENBERG, W. G., et al. Effects of Fire and Cattle Grazing on Longleaf Pine Standa as Studied by McNeill, Miss. U.S.D.A., Tech. Bulletin, 688, 1939.

16. YOUNG, V. A., et al. The Infnence of Sheep Grazing on Conifers Reproduction and Forage on Cut-over Western White Pine Areas in Northern Idaho. University of Idaho, Bulletin 6, 1942 . 